\title{
ASSESSMENT OF SOIL CHEMICAL PROPERTIES AND RICE YIELD IN TIDAL SUBMERGENCE ECOSYSTEM
}

\author{
M.A.A. Mamun ${ }^{1 *}$, M.M. Haque ${ }^{1}$, Q. A. Khaliq ${ }^{1}$, M.A. Karim ${ }^{1}$, \\ A.J.M.S. Karim ${ }^{1}$, A.J. Mridha ${ }^{2}$ and M.A. Saleque ${ }^{2}$ \\ ${ }^{1}$ Bangabandhu Sheikh Mujibur Rahman Agricultural University, Gazipur-1706 \\ ${ }^{2}$ Bangladesh Rice Research Institute, Gazipur-1701, Bangladesh \\ *Corresponding author: aamamunbrri@yahoo.com
}

Key words: Nitrogen, potassium, phosphorus, rice, , organic matter

\begin{abstract}
Spatial variability of soil chemical properties is critical for improving rice productivity and sustainable farming techniques. However, a systematic assessment on the spatial variability of tidal ecosystem has not been conducted. So, 144 soil samples were collected across Barisal, Borguna and Jalkhati districts and analyzed for six common chemical properties. Rice yield data was obtained by surveying farmers during crop harvest. Soil parameters and rice yield varied considerably throughout the study areas and their coefficients of variation ranged from 8.77 to $71.04 \%$. Slight variability was observed for soil organic matter (SOM) and available $\mathrm{K}$. The $\mathrm{pH}$ of the soils was slightly acidic to alkaline. These paddy fields were characterized by high concentrations of SOM, available P, K and S; but low total N. Rice yield was significantly and positively correlated with $\mathrm{pH}$, available $\mathrm{K}$ and $\mathrm{S}$, but negatively correlated with SOM.
\end{abstract}

\section{Introduction}

Low productive tidal submergence ecosystem is one of the major unfavorable agro-ecological zones in Bangladesh (Hossain et al., 2002) and covers about 2.0 M ha (Elahi et al., 2001). The northern half of these tidal wetlands is non-saline. The major environmental problem for crop production is twice daily tidal water inundation of land (Roy et al., 2003). Tidal water depth could be $6-90 \mathrm{~cm}$ during April to November with the highest peak in August (Debnath et al., 2013). Soil chemical properties are typically related to variability in crop yield and their degradation will result in a decrease of soil fertility and nutrients (Gray and Morant, 2003). Scientific information concerning spatial variability and distribution of soil properties is critical for farmers attempting to increase fertilizer use-efficiency and crop productivity. Fertilization based on soil fertility may also lead to reduced fertilizer inputs without reducing yield (Jalali, 2007). Assessing the spatial variability of soil chemical properties is crucial to design sustainable cropping systems.Moreover, the sedimentation associated with tidal flooding is an important source of nitrogen $(\mathrm{N})$, phosphorus $(\mathrm{P})$ and potassium $(\mathrm{K})$ (Saleque et al., 2010). In these sediments, $\mathrm{N}$ is deposited mostly as a component of organic matter (OM), whereas $\mathrm{P}$ is associated primarily with the fine-grained clay minerals (Odum, 1988). Understanding field spatial variation and the relationships with crop response may substantially increase the input effectiveness and average crop yield (Virgilio et al., 2007). Yamagishi et al. (2003) found that crop yield was significantly correlated with soil properties. Evaluating the spatial variability of rice yield and related chemical properties in low-yield paddy areas of tidal ecosystem is urgently needed for regional planning purposes. Therefore, the objectives of the present study were to estimate the current status and regional spatial variability of soil chemical properties and analyze the relationships between rice yield and selected chemical properties.

\section{Materials and Methods}

\section{Locations}


Mamun et al.

Soil samples were collected from 144 farmers' fields of Barisal, Borguna and Jalkhati district (Table 1). The area covers southern part of the country including and belongs to agro ecological zone-13, Ganges Tidal Floodplain of Bangladesh. This region occupies an extensive area of tidal floodplain land in the southern part of the country. The common cropping pattern is Fallow-Aus-Aman. The samples were collected in July, 2013.

Table 1. Number of soil samples collected across different locations in tidal areas

\begin{tabular}{l|c|c|c|c}
\hline Districts & Upazilas & Villages & Symbol & Number of samples \\
\hline Barisal & Gournadi & Pinglakhati & PK & 24 \\
& & Kutubpur & KT & 24 \\
& Bakergonj & Niamoti & NM & 24 \\
& & Char Boalia & CB & 24 \\
Borguna & Batagi & Bibichini & BB & 24 \\
Jalkhati & Nalchiti & Dopdopia & DP & 144 \\
\hline Total & & & & \\
\hline
\end{tabular}

\section{Collection and analysis of soil samples}

The soil samples of $0-15 \mathrm{~cm}$ depth were collected from selected plots to determine the physicochemical properties. The soil samples were air-dried, crushed and passed through $2 \mathrm{~mm}$ sieve and stored in polyethylene bags at room temperature, prior to analyze organic carbon and total nitrogen content. Soil organic carbon was analyzed by Walkley-Black wet oxidation method (Allison, 1965). A portion of $1.0 \mathrm{~g}$ air-dried soil sample (passed through $0.5 \mathrm{~mm}$ sieve) was taken in a $500 \mathrm{ml}$ Erlenmeyer flask. Ten $\mathrm{ml} 1 \mathrm{~N} \mathrm{~K}_{2} \mathrm{Cr}_{2} \mathrm{O}_{7}$ and $20 \mathrm{ml}$ conc. $\mathrm{H}_{2} \mathrm{SO}_{4}$ was added to the flask and allowed to react for 30 minutes after which $200 \mathrm{ml}$ distilled water and $10 \mathrm{ml}$ conc. $\mathrm{H}_{3} \mathrm{PO}_{4}$ was added. One ml orthophenanthroline indicator was added to the flask and was titrated with about $0.5 \mathrm{~N} \mathrm{FeSO}_{4}$ solution. Blank titration was run to calculate the strength of the $\mathrm{FeSO}_{4}$ solution.

Total nitrogen was determined following Bremner (1965) method, but Microkjeldahl instrument was used. A portion of $0.5 \mathrm{~g}$ air-dried soil sample was digested in $3 \mathrm{ml}$ conc. $\mathrm{H}_{2} \mathrm{SO}_{4}$ in the presence of 0.5 $\mathrm{g}$ of digestion mixture (50: 10: $1 \mathrm{~K}_{2} \mathrm{SO}_{4}: \mathrm{CuSO}_{4} \cdot 5 \mathrm{H}_{2} \mathrm{O}:$ metallic selenium). The digested sample was distillated with $40 \% \mathrm{NaOH}$ and the distillate was collected in $4 \%$ boric acid containing three drops of mixed indicator (bromocresol green and methyl red), which was then titrated with $0.05 \mathrm{~N} \mathrm{H}_{2} \mathrm{SO}_{4}$. $\mathrm{C}$ : $\mathrm{N}$ ratio was calculated by dividing the results of organic carbon by total nitrogen. All measurements of organic carbon and total nitrogen were done in triplicate. Soil $\mathrm{pH}$ in water was measured from a soil: water ratio 1: 2.5 using glass electrode method (Peech, 1965). Twenty gram of air-dried 80 sieved soil sample was taken in a $100 \mathrm{ml}$ of plastic bottle and $50 \mathrm{ml}$ of distilled water was added. The suspension was stirred with a glass-rod at regular interval for 30 minutes. A glass electrode $\mathrm{pH}$ meter calibrated with buffer $\mathrm{pH} 7.0$ and 4.0 and the $\mathrm{pH}$ of soil suspension was measured. The measurement was done in triplicate. Olsen-P was extracted with $0.5 \mathrm{M}$ sodium bicarbonate $(\mathrm{pH} 8.5)$ as outlined by (Olsen et al., 1954) and $\mathrm{P}$ content in the extract was determined using ascorbic acid as reducing agent by a spectrophotometer. Available potassium $\left(\mathrm{NH}_{4} \mathrm{OAc}-\mathrm{K}\right)$ was extracted with neutral $1 \mathrm{~N}$ ammonium acetate (Hanway and Heidel, 1952) and estimated by a flam photometer; available sulphur $\left(\mathrm{CaCl}_{2}-\mathrm{S}\right)$ was determined by extracting the soil samples with $0.15 \mathrm{CaCl}_{2}$ and sulphur concentration in the extract was estimated by turbidimetric method (Chesnin and Yien, 1950).

\section{Yield data collection}

Local Aman cultivars such as Lothor, Lalpyka, Kutiagoni, Mutha, Razashail, Sadapajam, Lalchikon, Sadachikon Sadamota, Lalmota and Moulata were cultivated by the farmers. Rice plants from $5 \mathrm{~m}^{2}$ area of the middle of each field were harvested at ground level and threshed. The grains were dried in sunlight and winnowed before weighing and the seed yield was adjusted to $14 \%$ moisture content. The descriptive statistics of chemical properties of collected soils were determined. Means, maximum, 
minimum, standard deviation, coefficient of variation and skewness of yield and soil chemical properties were determined. Computations were made using Excel software.

\section{Results and Discussion}

\section{Descriptive statistics}

Based on skewness values, grain yield, $\mathrm{pH}, \mathrm{SOM}, \mathrm{N}, \mathrm{P}, \mathrm{K}$ and $\mathrm{S}$ were normally distributed. A wide range was observed for each soil chemical parameter. The coefficient of variation $(\mathrm{CV})$ values for all selected parameters ranged from 8.77 to $71.04 \%$. Notably, a relatively small CV value $(8.77 \%)$ was observed for $\mathrm{pH}$, while a relatively large $\mathrm{CV}$ value was obtained for $\mathrm{P}$ (71.04\%). Soil $\mathrm{pH}$ influences the solubility of phosphorus, zinc and many other nutrients (Lindsey, 1979). Changes in $\mathrm{pH}$ due to soil submergence during wetland rice growth may alter considerably the availability of nutrients from those predicted by soils tests based on nutrient extractions from dry soil samples. Besides acting as a source of nutrients, soil organic matter also has very important functions related to nutrient availability and retention. These should also take into consideration that the nutrient input from tidal sediments, which may contribute considerably to crop nutrition. Others have also reported similar findings at various scales (Fu et al., 2010).

Table 2. Statistical summery of grain yield and soil chemical properties

\begin{tabular}{l|ccccc|c|c}
\hline \multirow{2}{*}{ Variables } & \multicolumn{7}{c}{ Descriptive statistics } \\
\cline { 2 - 7 } & Mean & Minimum & Maximum & Standard deviation & CV (\%) & Skewness \\
\hline Yield $\left(\mathrm{t} \mathrm{ha}^{-1}\right)$ & 2.71 & 1.26 & 3.98 & 0.621 & 22.89 & -0.08 \\
$\mathrm{pH}$ & 6.55 & 5.04 & 7.58 & 0.574 & 8.77 & -0.08 \\
$\mathrm{SOM}(\%)$ & 2.31 & 1.41 & 3.35 & 0.336 & 14.51 & 0.05 \\
$\mathrm{~N}(\%)$ & 0.113 & 0.075 & 0.160 & 0.020 & 17.87 & 0.16 \\
$\mathrm{P}\left(\mathrm{mg} \mathrm{kg}^{-1}\right)$ & 10.58 & 0.490 & 41.15 & 7.51 & 71.04 & 0.95 \\
$\mathrm{~K}(\mathrm{meq} / 100 \mathrm{~g})$ & 0.16 & 0.092 & 0.230 & 0.038 & 23.63 & 0.20 \\
$\mathrm{~S}\left(\mathrm{mg} \mathrm{kg}^{-1}\right)$ & 18.41 & 6.52 & 39.26 & 7.23 & 39.27 & 0.74 \\
\hline
\end{tabular}

Spatial variation in soil chemical properties

A great variation in soil chemical properties existed across different locations. The mean value of soil $\mathrm{pH}$ ranged from 6.03 to 7.07 . The maximum soil $\mathrm{pH}$ at Pinglakhati $(\mathrm{PK})$ of Gournadi and the minimum at Bibichini (BB) of Batagi were recorded (Fig. 1). The maximum and minimum values of $\mathrm{pH}$ were 7.58 and 5.26; 7.46 and 6.40; 7.18 and 5.60; 7.44 and 5.04; 6.61 and 5.60; and 7.04 and 6.51 at Pinglakhati (PK), Kutubpur (KT), Niamoti (NM), Char Boalia (CB), Bibichini (BB) and Dopdopia (DP), respectively. Saleque et al. (2010) also reported that most of the delta soil had pH values in the top soil ranging from slightly acidic to moderate alkaline. Slight acidity was found in some fields indicates that soil was probably an acid soil. Many of alkanline soil reaction, presumably resulting from repeated equilibrium with surface water and ground water that were influenced by sea water carrying neutral and chloride salts. 
Mamun et al.
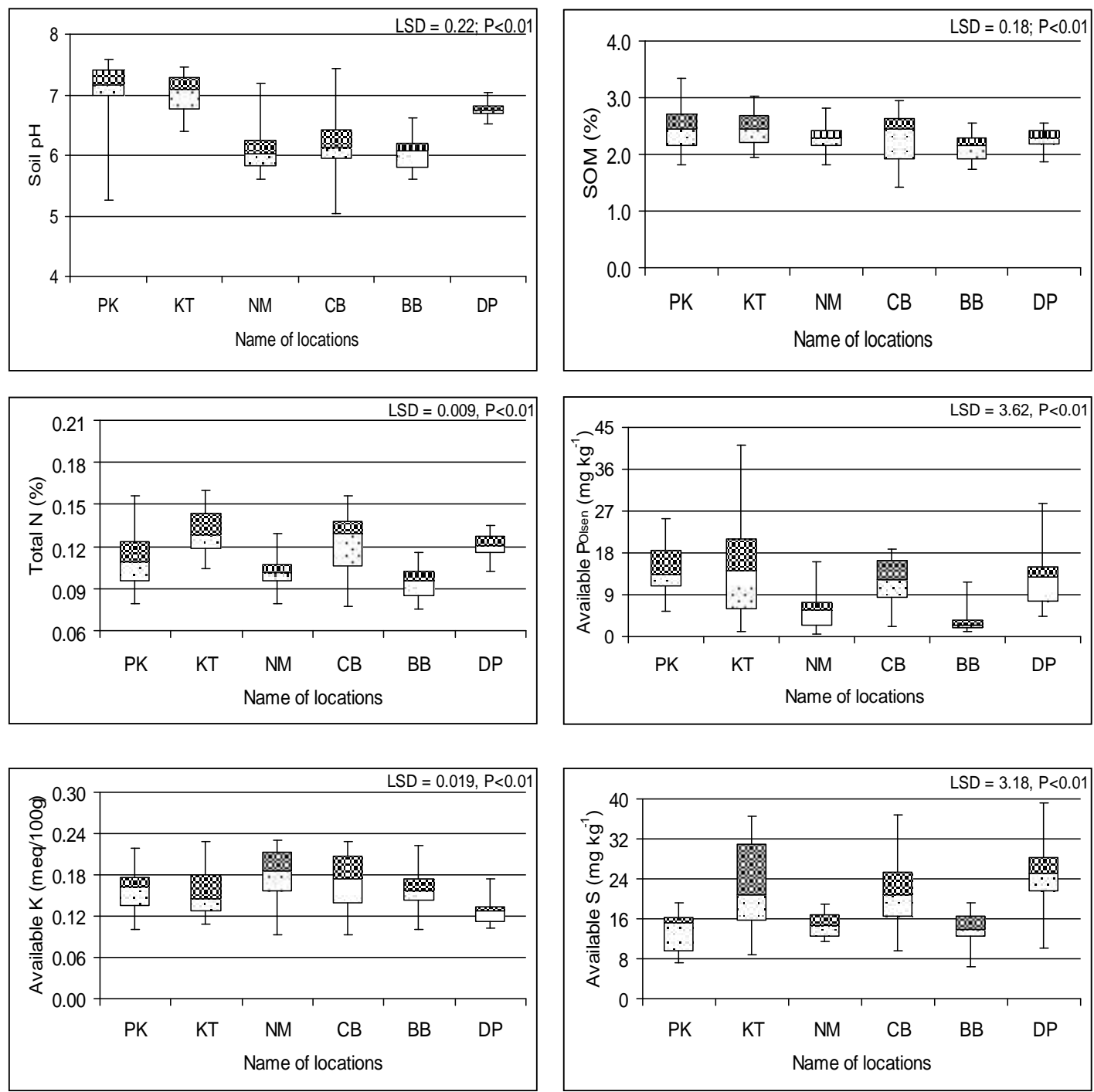

Fig. 1. Comparison of soil properties among the locations. The white and black boxes indicate $2^{\text {nd }}$ and $3^{\text {rd }}$ quartiles. The line between two bars represent the mean value. $\mathrm{PK}=$ Pinglakhati, $\mathrm{KT}=$ Kutubpur, NM = Niamoti, $\mathrm{CB}=$ Char Boalia, $\mathrm{BB}=$ Bibichini and DP = Dopdopia.

The SOM content was almost similar among locations. The average SOM varied from 2.10 to $2.48 \%$. The maximum SOM (3.35\%) was recorded from PK and minimum (1.41\%) from CB. The locations were flooded twice daily and rich in SOM. The relatively high SOM concentration PK and KT soil could be attributed to the prolonged submergence and growth of natural aquatic plants during the period when the soil was flooded. On the other hand, the water logging of tidal soils might reduce decomposition of SOM, causing higher SOM concentration. Little variation was observed in spatial distribution of total $\mathrm{N}(\%)$ across the locations. The mean value of total $\mathrm{N}$ ranged from 0.09 to $0.13 \%$. Maximum total $\mathrm{N}$ was obtained from KT and minimum from PK and CB. The critical value of total $\mathrm{N}$ in soil is $0.12 \%$ (Shah et al., 2008). The obtained total $\mathrm{N}$ was less than critical limit. There was a great variation in spatial distribution of available $\mathrm{P}$ across the locations (Fig. 1). The mean value of available $\mathrm{P}$ ranged from 3.10 to $12.09 \mathrm{mg} \mathrm{kg}^{-1}$. Maximum available $\mathrm{P}$ was obtained from KT and 
minimum from NM. The critical value of available $\mathrm{P}$ in soil is $8.0 \mathrm{mg} \mathrm{kg}^{-1}$ (Shah et al., 2008). The obtained available $\mathrm{P}$ was much higher than critical limit in some location. Tidal flooded soils are replenished with $\mathrm{P}$ through tidal sediments, which can contain considerable amounts of total and available P (Saleque et al., 2010). The variation was less in available K across the locations. The mean value of available $\mathrm{K}$ ranged from 0.13 to $0.16 \mathrm{meq} / 100 \mathrm{~g}$. Maximum available $\mathrm{K}$ was obtained from NM and minimum from DP. The critical value of available K in soil is $0.12 \mathrm{meq} / 100 \mathrm{~g}$ (Shah et al., 2008). The obtained available $\mathrm{K}$ was much higher than critical limit in some location. Saleque et al. (2010) also reported that exchangeable K concentration of tidal soil was high. It might be due to carrying $\mathrm{K}$ through tidal water. There was a great variation in spatial distribution of available $\mathrm{S}$ across the locations. The mean value of available $S$ ranged from 13.15 to $24.90 \mathrm{mg} \mathrm{kg}^{-1}$. Maximum available $\mathrm{S}$ was obtained from DP and minimum from PK. The critical value of available $\mathrm{S}$ in soil is $10.0 \mathrm{mg}$ $\mathrm{kg}^{-1}$ (Shah et al., 2008). The obtained available $\mathrm{S}$ was much higher than critical limit in some location. The tidal water contains some amount of $\mathrm{K}$ and $\mathrm{P}$. Thus the amount of soil $\mathrm{K}$ and $\mathrm{P}$ were much higher than critical value. However, soil S was also higher than critical value because of higher SOM content and organic is the main source of $\mathrm{S}$ in soil.

\section{Spatial variation in grain yield}

The yield of rice varied depending on locations. The average grain yield was 2.56, 2.90, 2.33, 3.06, 2.48 and $2.96 \mathrm{t} \mathrm{ha}^{-1}$ in PK, KT, NM, CB, BB and DP, respectively. The maximum grain yield was obtained from CB $\left(3.98 \mathrm{t} \mathrm{ha}^{-1}\right)$ and minimum from $\mathrm{CB}\left(1.26 \mathrm{t} \mathrm{ha}^{-1}\right)$. The minimum and maximum yield at PK, KT, NM, CB, BB and DP were 1.37 to $3.63 ; 1.77$ to $3.75 ; 1.40$ to $3.0 ; 1.26$ to $3.98 ; 1.54$ to 3.26 and 1.48 to 3.92 , respectively (Fig. 2). However, farmers did not apply fertilizers. It is often impossible to follow recommended practices of nutrient management like nitrogen $(\mathrm{N})$ fertilizer because there is a high risk of surface $\mathrm{N}$ losses to floodwater.

\section{Correlation between selected parameters}

To characterize the relationships between yield and selected soil chemical properties $(\mathrm{pH}, \mathrm{SOM}, \mathrm{N}, \mathrm{P}$, $\mathrm{K}$ and S), Pearson's product moment correlation coefficient was calculated for each property (Table 3). The results indicated that rice yield was strongly and positively correlated with $\mathrm{pH}, \mathrm{K}$ and $\mathrm{S}$, and negatively with SOM. Moreover, no significant correlation was observed between rice yield and $\mathrm{N}$ or P. This results support the findings of Liu et al. (2014).

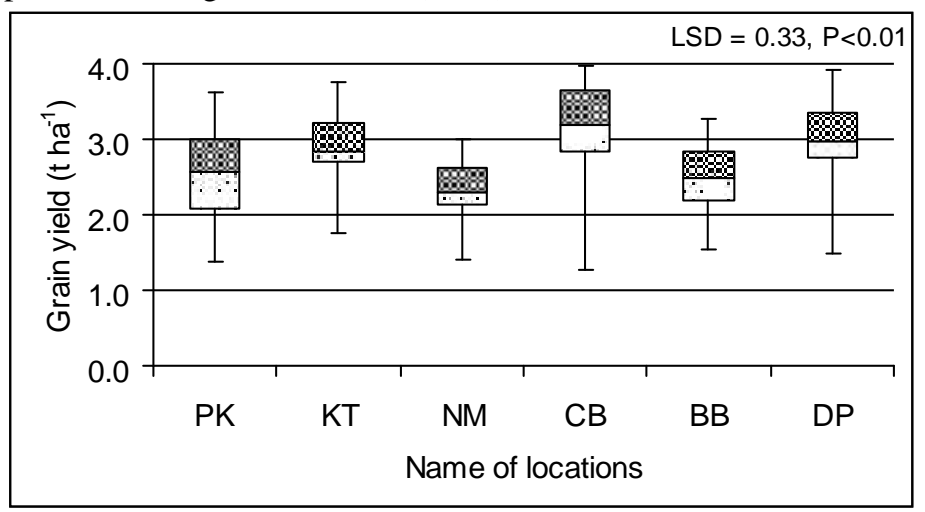

Fig. 2. Comparison of grain yield among the locations. The white and black boxes indicate $2^{\text {nd }}$ and $3^{\text {rd }}$ quartiles. The line between two bars represent the mean value. $\mathrm{PK}=$ Pinglakhati, $\mathrm{KT}=$ Kutubpur, $\mathrm{NM}=$ Niamoti, $\mathrm{CB}=$ Char Boalia, $\mathrm{BB}=$ Bibichini and DP $=$ Dopdopia.

Table 3. Correlation coefficients (Pearson's test) of rice yield and soil properties

\begin{tabular}{l|l|l|l|l|l|l|l}
\hline & Yield & $\mathrm{pH}$ & $\mathrm{SOM}$ & $\mathrm{N}$ & $\mathrm{P}$ & $\mathrm{K}$ & $\mathrm{S}$ \\
\hline
\end{tabular}


Mamun et al.

\begin{tabular}{|c|c|c|c|c|c|c|c|}
\hline & $\left(\mathrm{t} \mathrm{ha}^{-1}\right)$ & & $(\%)$ & $(\%)$ & $\left(\mathrm{mg} \mathrm{kg}^{-1}\right)$ & (meq/100g) & $\left(\mathrm{mg} \mathrm{kg}^{-1}\right)$ \\
\hline Yield $\left(\mathrm{t} \mathrm{ha}^{-1}\right)$ & 1 & & & & & & \\
\hline $\mathrm{pH}$ & $0.371 * *$ & 1 & & & & & \\
\hline SOM (\%) & $-0.157 *$ & -0.020 & 1 & & & & \\
\hline $\mathrm{N}(\%)$ & 0.073 & 0.089 & $0.863 * *$ & 1 & & & \\
\hline $\mathrm{P}\left(\mathrm{mg} \mathrm{kg}^{-1}\right)$ & 0.096 & $0.321 * *$ & $0.403 * *$ & $0.522 * *$ & 1 & & \\
\hline $\mathrm{K}(\mathrm{meq} / 100 \mathrm{~g})$ & $0.160 *$ & -0.129 & 0.102 & -0.009 & 0.077 & 1 & \\
\hline $\mathrm{S}\left(\mathrm{mg} \mathrm{kg}^{-1}\right)$ & $0.293 * *$ & $0.140 *$ & 0.066 & $0.362 * *$ & $0.194 *$ & $-0.129 *$ & 1 \\
\hline
\end{tabular}

$* \mathrm{P}<0.05$ and $* * \mathrm{P}<0.01$.

To determine whether a curve-linear relationship exists between the rice yield and nine soil nutrient parameters, regression analysis with the scatter plot was carried out (Fig. 3). The result illustrated that there was no typical curve-linear relationship between the rice yield and soil nutrients, although the yield to $\mathrm{pH}$ can be fitted slightly linear equation (Fig. 3) very poor $\mathrm{R}^{2}$ values. Similar to correlation analysis, these linear regressions confirmed that rice yield increased substantially with soil $\mathrm{pH}$, available $\mathrm{K}$ and $\mathrm{S}$, while it showed a slight decreasing trend to soil organic matter. Fairhurst et al. (2007) reported that low land rice in delta soil would rarely respond to the application of K. Moreover, considerable $\mathrm{K}$ input from tidal sediments can contribute to the $\mathrm{K}$ nutrition of rice in this area. Saleque et al. (2010) also reported that none of tidal soils analyzed was deficient in $\mathrm{S}$ for wetland rice and considerable $\mathrm{S}$ input from the deposition of tidal sediments could be expected.
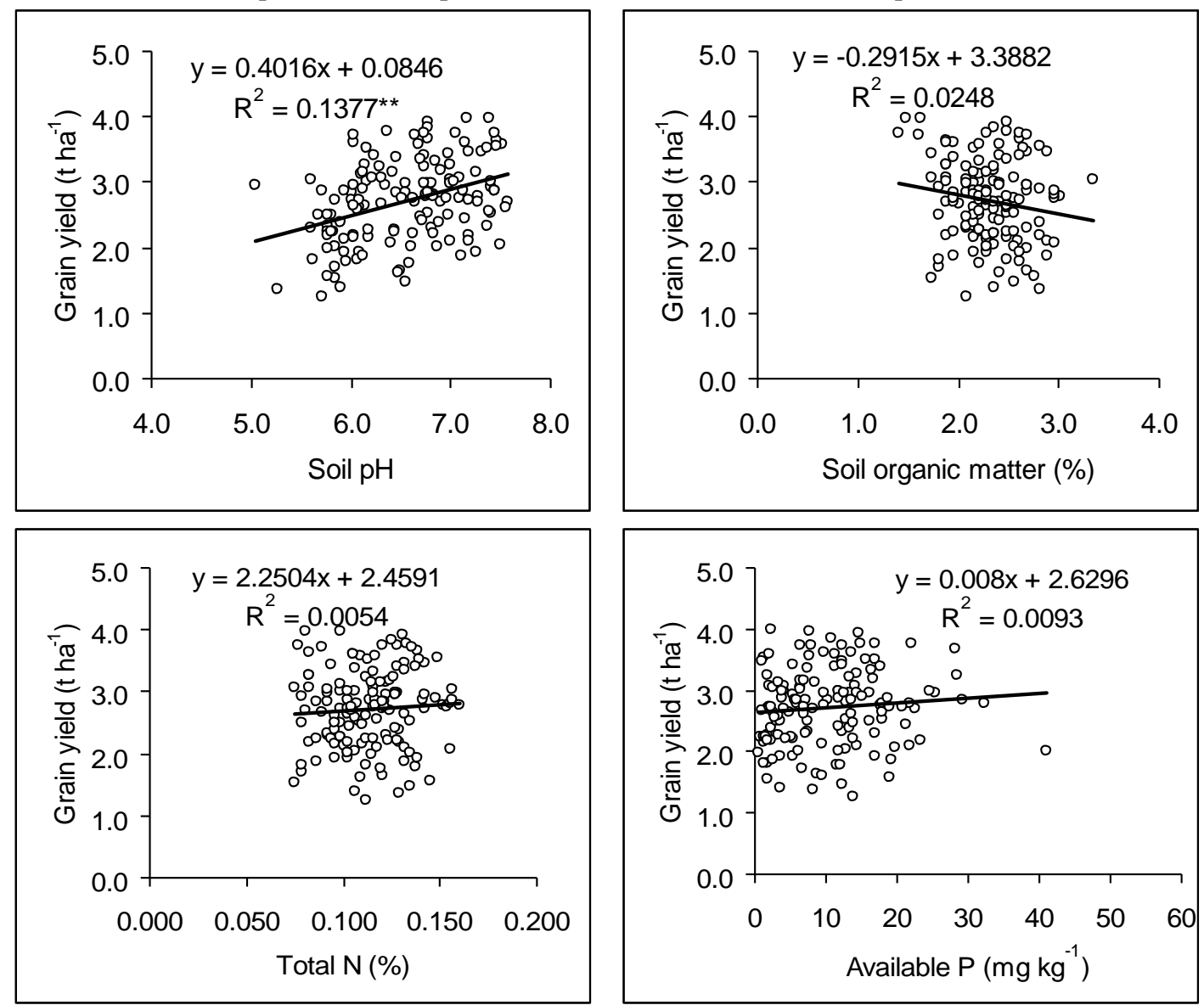

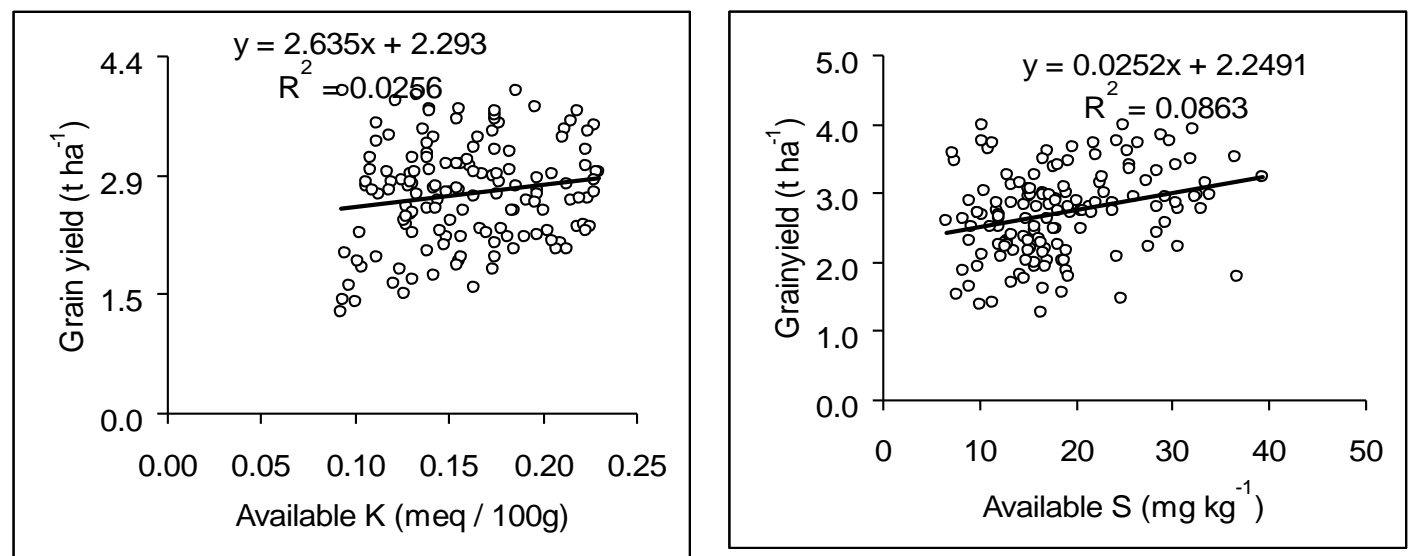

Fig. 3. Regression analysis between rice yield and soil properties.

This result supports the findings of Ilstedt et al. (2003). Numerous studies have reported that SOM is positively and highly correlated with rice yield (Pan et al., 2009), while an opposite finding was observed in our study. Such unconformity may explain the negative correlation between rice yield and SOM. Low decomposition rate and less microbial activity due to tidal flooding may be the cause of negative relationship between yield and SOM.

\section{Conclusion}

The entire tidal flood prone area was characterized by neutral soil $\mathrm{pH}$, high concentrations of SOM, P, $\mathrm{K}$ and $\mathrm{S}$. Low levels of $\mathrm{N}$ may be the major factors limiting rice production due to their positive effects on rice yield. On the basis of those results, $\mathrm{N}$ fertilizer must be applied but deep placement should be advocated to avoid loss in tidal water.

\section{References}

Allison, L. E. 1965. Organic carbon. In: C. A. Black (eds). Methods of soil analysis, Part 2. ASA, Madison, USA, pp. 539-577.

Bremner, J. M. 1965. Total nitrogen. In: C. A. Black (eds). Methods of soil analysis, Part 2. ASA, Madison, USA, pp. 595-622pp.

Debnath, M., M. T. Islam, E. J. Emi, S. Hasna, M. H. O. Rashid and S. C. Smanta. 2013. An effect of fertilizer management practices on the yield of $\mathrm{T}$. aman rice under tidal ecosystem. American Journal of Agriculture and Forestry 1(4): 74-79.

Elahi, N. E., M. A. H. Khan, M. A. I. Khan, M. R. Islam, M. A. Salam, M.A. Hossain and A. U. Ahmed. 2001. Research report of the tidal non-saline sub-ecosystem for the year 2001. IFAD planning meeting held on 13 January, 2001, Dhaka, Bangladesh.

Fairhurst, T. H., C. Witt, R. J. Buresh and A. Dobermann. 2007. Rice: A practical guide to nutrient management, $2^{\text {nd }}$ edn. International Plant Nutrition Institute and International Potash Institute. International Rice Research Institute. Metro manila, 89 pp.

Fu, W. J., H. Tunney and C. S. Zhang. 2010. Spatial variation of soil nutrients in a dairy farm and its implications for site-specific fertilizer application. Soil Tillage Res. 106, 185-193.

Gray, L. C. and P. Morant. 2003. Reconciling indigenous knowledge with scientific assessment of soil fertility changes in southeast Burkina Faso. Geoderma 111: 425-437. 
Mamun et al.

Hossain, M. A., B. C. Roy, S. S. Haque, M.A. I. Khan and A. W. Julfiquar. 2002. Potentiality of hybrid rice in the south central region of Bangladesh. Hybrid rice in Bangladesh, Progress and Future Strategies. Bangladesh Rice Research Institute, pp: 51-52.

Ilstedt, U., R. Giesler, A. Nordgren and A. Malmer. 2003. Changes in soil chemical and microbial properties after a wildfire in a tropical rainforest in Sabah, Malaysia. Soil Biol. Biochem. 35: 1071-1078.

Jalali, M. 2007. Spatial variability in potassium release among calcareous soils of western Iran. Geoderma 140: 42-51.

Jin, J. Y. and C. Jiang. 2002. Spatial variability of soil nutrients and site specific nutrient management in the P.R. China. Comput. Electron. Agric. 36: 165-172.

Lindsey, W. L. 1979. Chemical Equilibria in Soils. John Wiley \& Sons Inc, New York.

Liu, Z., W. Zhou, J. Shen, P. He, Q. Lei and G. Liang. 2014. A simple assessment on spatial variability of rice yield and selected soil chemical properties of paddy fields in South China. Geoderma 235236: 39-47.

Odum, W. E. 1988. Comparative ecology of tidal freshwater and salt marshes. Annual Review of Ecological Syatem. 19: 147-176.

Olsen, S. R., C. V. Cole, F. S. Watanable and L. A. Dean. 1954. Estimation of available Phosphorus in soils by extraction with sodium bicarbonate. US dept. Agric. Circular, p. 939.

Pan, G. X., P. Smith and W. N. Pan. 2009. The role of soil organic matter in maintaining the productivity and yield stability of cereals in China. Agric. Ecosyst. Environ. 129: 344-348.

Peech, M. 1965. Hydrogen ion activity. In: C. A. Black (eds). Methods of soil analysis, Part 2. Chemical and microbiological properties \# 9, ASA, Madison, USA, pp. 914-925.

Roy, B. C., M. A. Hossain and M. A. I. Khan. 2003. Suitable transplanting time for modern T. aman rice varieties in tidal nonsaline wetland situation in Bangladesh. Pakistan J. Biol. Sci. 6(7): 661-665.

Saleque, M. A., M. K. Uddin, M. A. Salam, A. M. Ismail and S. M. Haefelo. 2010. Soil characteristics of saline and non-saline deltas of Bangladesh. Tropical deltas and coastal zones: Food production, communities and environment at the land-water interface. p. 145-152.

Shah, Z., W. Malik, A. Bhatti and H. Rahman. 2013. Spatial variability of nutrients in wheat plant in semiarid regions of Northwestern Pakistan. Commun. Soil Sci. Plant Anal. 44: 2472-2487.

Shah, A. L., M. R. Islam, M. M. Haque, M. Ishaque and M. A. M. Miah. 2008. Efficacy of major nutrients in rice production. Bangladesh J. Agril. Res. 33(3): 639-645.

Virgilio, N. D., A. Monti and G. Venturi. 2007. Spatial variability of switchgrass (Panicum virgatum L.) yield as related to soil parameters in a small field. Field Crop Res. 101: 232-239.

Yamagishi, J., T. Nakamoto and W. Richner. 2003. Stability of spatial variability of wheat and maize biomass in a small field managed under two contrasting tillage. Field Crop Res. 81: 95-108. 